\title{
Heart-kidney crosstalk and role of humoral signaling in critical illness
}

Grazia Maria Virzi ${ }^{1,2,3^{*}}$, Sonya Day ${ }^{1,2}$, Massimo de Cal ${ }^{1,2}$, Giorgio Vescovo ${ }^{4}$ and Claudio Ronco ${ }^{1,2}$

\begin{abstract}
Organ failure in the heart or kidney can initiate various complex metabolic, cell-mediated and humoral pathways affecting distant organs, contributing to the high therapeutic costs and significantly higher morbidity and mortality. The universal outreach of cells in an injured state has myriad consequences to distant organ cells and their milieu. Heart performance and kidney function are closely interconnected and communication between these organs occurs through a variety of bidirectional pathways. The term cardiorenal syndrome (CRS) is often used to describe this condition and represents an important model for exploring the pathophysiology of cardiac and renal dysfunction. Clinical evidence suggests that tissue injury in both acute kidney injury and heart failure has immune-mediated inflammatory consequences that can initiate remote organ dysfunction. Acute cardiorenal syndrome (CRS type 1) and acute renocardiac syndrome (CRS type 3) are particularly relevant in high-acuity medical units. This review briefly summarizes relevant research and focuses on the role of signaling in heart-kidney crosstalk in the critical care setting.
\end{abstract}

\section{Introduction}

Heart performance and kidney function are closely interconnected, and communication between these organs occurs through a variety of bidirectional pathways. The severity of the failing organ can initiate various complex metabolic, cell-mediated and humoral pathways affecting distant organs, contributing to the high therapeutic costs and significantly higher morbidity and mortality. Both

\footnotetext{
* Correspondence: grazia.virzi@gmail.com

'Department of Nephrology, Dialysis and Transplantation, San Bortolo Hospital, International Renal Research Institute Vicenza, Via Rodolfi 37, Vicenza 36100, Italy

${ }^{2}$ IRRIV - International Renal Resarch Institute Vicenza, Via Rodolfi 37, Vicenza 36100, Italy

Full list of author information is available at the end of the article
}

acute and chronic cardiac disease can directly contribute to concurrent acute/chronic worsening kidney function and the converse $[1,2]$. The term cardiorenal syndrome (CRS) is often used to describe this condition, representing an important model for exploring the pathophysiology of cardiac and renal dysfunction [1,3]. The CRS classification system includes a vast array of acute or chronic conditions in these two important organs, where the primary failing organ can be either the heart or the kidneys. The current definition has been expanded into five subtypes whose etymology reflects the primary and secondary pathology, the time frame, as well as cardiac and renal co-dysfunction secondary to systemic disease [1] (Table 1). Epidemiological studies of CRS indicate that patients transition between different CRS subtypes [4]. There are a number of potential contributing factors for CRS that may predispose a patient to the development of this syndrome and which are relevant for the susceptibility, etiology, severity and duration of the disease state. The intersection of cardiac and renal disorders has important therapeutic and prognostic implications; this new classification represents a step towards a better understanding of the pathophysiology and management strategies of this bidirectional crosstalk.

Clinical evidence suggests that tissue injury such as acute kidney injury (AKI) is not an isolated event and it has become apparent that much of the increased risk of death is derived from distant complications $[5,6]$. A recent multicenter, multinational study reported that 5 to $6 \%$ of these at-risk patients suffer from AKI and subsequently are treated with renal replacement therapy (RRT) [7]. Twenty-five percent of patients in the ICU develop AKI $[8,9]$. RRT is the only US Food and Drug Administration-approved treatment for AKI [10,11]. For more than 40 years, despite the advent of RRT, there has been limited improvement in the mortality rate associated with AKI [12]. In the critical care setting, AKI remains an important predictor of outcome, and frequently results in remote organ dysfunction involving the heart, lung, liver, intestines, and brain through 
Table 1 Cardiorenal syndrome classification system

\begin{tabular}{|c|c|c|}
\hline Classification & Abbreviation & Characteristic \\
\hline $\begin{array}{l}\text { Acute cardiorenal } \\
\text { syndrome }\end{array}$ & CRS type 1 & $\begin{array}{l}\text { Abrupt worsening of cardiac function leading to acute kidney injury; for example, acute coronary syndrome } \\
\text { causing acute heart failure and then renal dysfunction }\end{array}$ \\
\hline $\begin{array}{l}\text { Chronic cardiorenal } \\
\text { syndrome }\end{array}$ & CRS type 2 & $\begin{array}{l}\text { Chronic abnormalities in cardiac function causing progressive chronic kidney disease; for example, } \\
\text { congestive cardiac failure }\end{array}$ \\
\hline $\begin{array}{l}\text { Acute renocardiac } \\
\text { syndrome }\end{array}$ & CRS type 3 & $\begin{array}{l}\text { Sudden worsening of renal function causing acute cardiac dysfunction; for example, uremic } \\
\text { cardiomyopathy secondary to acute renal failure }\end{array}$ \\
\hline $\begin{array}{l}\text { Chronic renocardiac } \\
\text { syndrome }\end{array}$ & CRS type 4 & $\begin{array}{l}\text { Condition of primary chronic kidney disease leading to an impairment of the cardiac function and/or } \\
\text { increased risk of adverse cardiovascular events; for example, left ventricular hypertrophy and diastolic heart } \\
\text { failure secondary to renal failure }\end{array}$ \\
\hline $\begin{array}{l}\text { Secondary cardiorenal } \\
\text { syndrome }\end{array}$ & CRS type 5 & Systemic disorders causing both cardiac and renal dysfunction; for example, septic shock, vasculitis \\
\hline
\end{tabular}

CRS, cardiorenal syndrome.

immune-mediated inflammatory mechanisms [13-15]. In the organ crosstalk, the combination of AKI with acute lung injury remains a formidable challenge for clinicians treating critically ill patients. New experimental data have emerged in recent years focusing on the interactive effects of kidney and lung dysfunction, and providing evidence that kidney-lung crosstalk occurs and can be bidirectionally deleterious. These studies have highlighted the pathophysiological importance of proinflammatory and proapoptotic pathways in the kidneylung crosstalk [16,17]. Inflammatory dysregulation resulting from each organ failure results in rising levels of circulating chemokines, cytokines and activated lymphocytes [17]. Cellular (for example, neutrophils) as well as soluble mediators (cytokines) contribute to the inflammatory dysregulation under these circumstances [18].

The liver and kidney are important regulators of body homeostasis and are involved in excreting the toxic byproducts of metabolism and exogenous drugs [19]. Liver injury often correlates with severity of kidney injury. AKI induces oxidative stress and promotes inflammation (production of TNF $\alpha$, IL-1, IL-6), apoptosis and tissue damage in hepatocytes [20-23]. Another important mechanism of end-organ dysfunction in kidney-liver crosstalk is the development of hepatorenal syndrome, a functional renal failure that often occurs in patients with cirrhosis and ascites. Two different types of hepatorenal syndrome have been described. Hepatorenal syndrome type 1 develops as a consequence of a severe reduction of effective circulating volume due to both an extreme splanchnic arterial vasodilatation and a reduction of cardiac output. Hepatorenal syndrome type 2 is characterized by a stable or slowly progressive renal failure, so that its main clinical consequence is not acute renal failure but refractory astrocytes, and its impact on prognosis is less negative [24,25]. Effects of AKI on the brain and the nervous system include several clinical signs [26]. In addition, cerebral inflammation and functional changes were demonstrated after AKI $[27,28]$. AKI also led to increased levels of proinflammatory chemokines, keratinocyte-derived chemoattractant, and granulocyte colony-stimulating factor in the cerebral cortex and hippocampus, which may function to recruit neutrophils to sites of neuronal damage, and to increased expression of glial fibrillary acidic protein in astrocytes in the cortex and corpus callosum [23]. AKI also induces a cell-mediated inflammatory response in the brain by activation of microglial cells (brain macrophages) [23].

In cardiorenal crosstalk, acute cardiorenal syndrome (CRS type 1) and acute renocardiac syndrome (CRS type 3) are particularly relevant in high-acuity medical units; in particular, CRS type 1 is often seen in the coronary care unit and in the ICU (Figure 1). The purpose of this review is to examine the burden of concomitant heart and renal dysfunction in critically ill patients. Recent work on AKI has shown that inflammatory cascades, cell adhesion molecule, cytokine and chemokine upregulated expression, neutrophil migration, leukocyte trafficking, caspase-mediated apoptosis, and oxidative stress putatively induce distant organ dysfunction [27]. During AKI, chemokines recruit neutrophil infiltration into the heart and cause myocyte apoptosis [29,30]. Additional complications include oxidative loss of redox homeostasis in reactive oxygen species (ROS) and reactive nitrogen species, resulting in a proinflammatory and profibrotic milieu via distinct mechanisms that promote cardiovascular and renal structural and functional abnormalities, including ischemia/reperfusion injury (IRI) [31,32]. The physiological crosstalk is necessary to maintain regular homeostasis and normal functioning of the organism. However, in the diseased state, the immediate and concomitant induction of toxic cell signaling by the primary damaged organ can induce structural and functional dysfunction in distant organs [33].

The evaluation of known mechanisms and putative targets underlying the pathophysiology of heart-kidney crosstalk encompasses innate and adaptive immunity, 


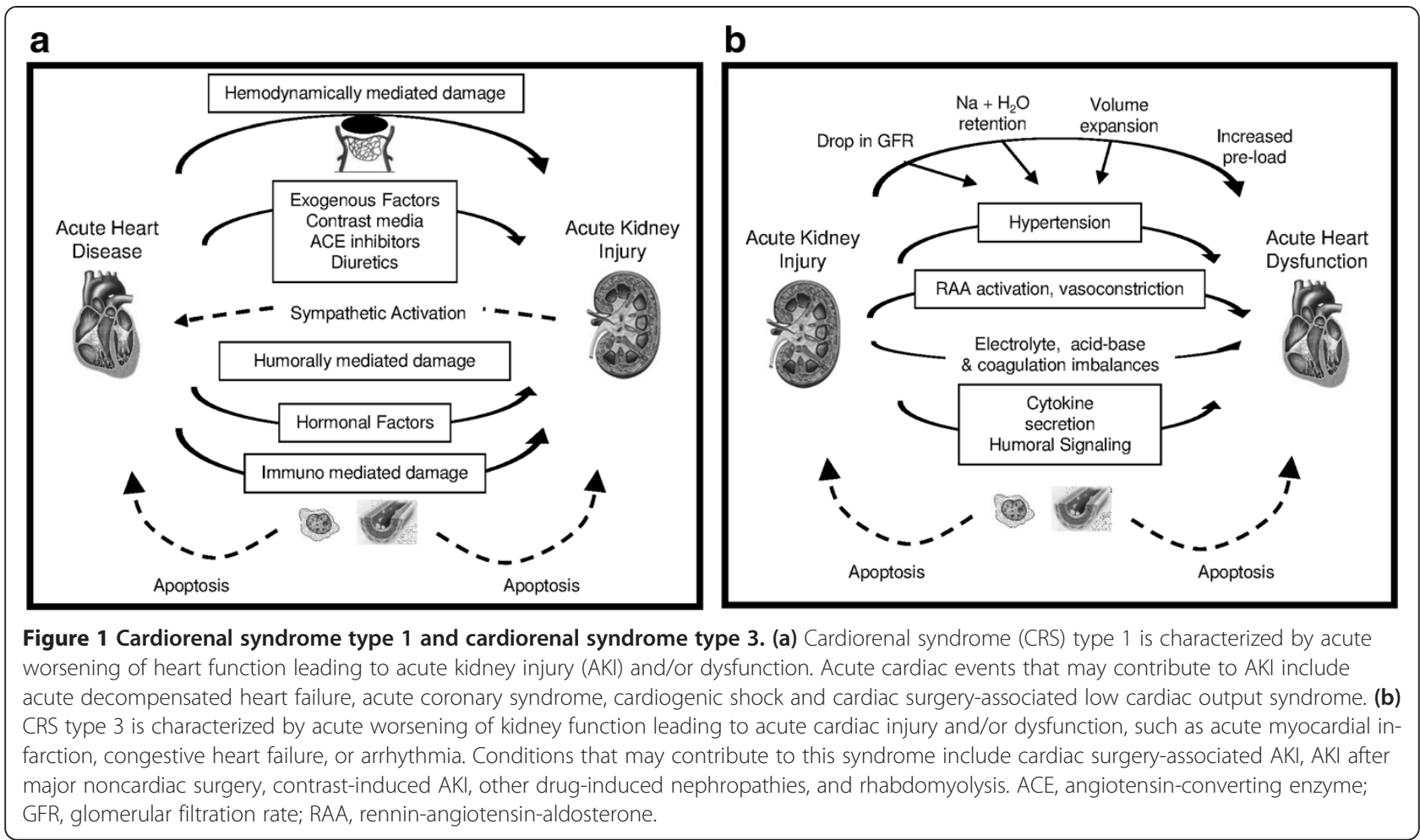

inflammation, cytokine and chemokine release, cell apoptosis, renal tubular epithelium and renal vascular endothelium alterations.

\section{Renal tubular epithelium and renal vascular endothelium}

The proximal tubular epithelial cells reabsorb numerous substances from the 140 liters of plasma ultrafiltrate that the normal kidney produces each day, substances that include small peptides and immune regulatory molecules as well as electrolytes and nitrogenous waste products [34]. Proximal tubular cells also actively secrete molecules from the peritubular capillary bed into the tubular lumen. Finally, proximal tubular cells are immunologically active, presenting antigen and producing a variety of inflammatory mediators [35-39].

The CD40/CD40-ligand (CD40L) pathway is a key mediator of cellular responses to injury and the resulting vascular pathophysiology. CD40 is a cell surface glycoprotein that belongs to the TNF-receptor superfamily, largely expressed on the cellular surface of antigenpresenting cells, including B lymphocytes, macrophages, and dendritic cells. CD40 is also present in some nonlymphoid cells, such as tubular epithelial cells, where it has been suggested to play a role in the pathogenesis of renal inflammatory response $[40,41]$. Stimulation in response to injury of CD40 receptor-CD40L has pleiotropic effects both on immune and nonimmune cells including downstream cellular and humoral immune response, microglial activation, and TNF $\alpha$ production. CD40/CD40L interaction induces in vitro the production of different proinflammatory cytokines, including IL-8, monocyte chemoattractant protein-1, and RANTES, by proximal tubular epithelial cells and modulates the response to inflammatory stimuli $[40,42]$. These different cytokines, chemokines, and adhesion molecules serve as chemoattractants for additional leukocytic infiltrates, including monocytes and $\mathrm{T}$ lymphocytes $[43,44]$. In particular, Laxmanan and colleagues found that human renal proximal tubular epithelial cells treated with soluble CD40L to ligate CD40 showed a significant increase in the generation of proinflammatory ROS; however, CD40-activated cells did not undergo apoptosis [45].

Recently, some studies focused on the contribution of tubular epithelial cells to the typical systemic inflammatory response of CRS and other pathologic conditions $[29,46]$. Complex signaling systems including crosstalks, feedback and feedforward loops polarize the cellular milieu in the pathophysiological profile, and include the expression of co-stimulatory pathways. An inexorable assemblage of evidence indicates that the clinical patterns in heart and kidney dysfunction are a direct result of cellular and subcellular remodeling processes [47-52]. Furthermore, renal tubular cells play a critical role in the handling of inflammatory mediators and in their resulting efflux into systemic circulation [50,53]. These cells contribute to the circulating levels of inflammatory mediators by different mechanisms, including epigenetic 
processes. These processes are driven by changes in covalent modifications of DNA and associated proteins, alterations in chromatin structure, and recruitment of a diversity of signal responsive transcription factors and enzymes [54,55]. In particular, Zager and Johnson demonstrated the upregulation of histone-modifying enzyme systems and the alteration of histone expression at proinflammatory and profibrotic genes such as TNFa and monocyte chemoattractant protein-1 in IRI [56-58].

Allam and colleagues recently identified extracellular histones as mediators of postischemic and septic AKI. Histones are released from dying tubular epithelial cells and act as damage-associated molecular patterns, which require toll-like receptor (TLR) 2 and TLR4 for the induction of proinflammatory cytokines; extracellular histones aggravate AKI via both its direct toxicity to renal endothelial cells and tubular epithelial cells and its proinflammatory effects [59].

Epigenetic changes, cellular signaling and humoral pathways create the cellular milieu and pathophysiological profile, depending on the timing, disease setting, and stimulation state. These biological events may play a role in heart-kidney crosstalk and in the increase of systemic inflammation and distant organ injury.

Renal vascular endothelial cells initiate early inflammatory responses in the injured kidney by direct contact with injurious agents [60]. The injured kidney is known to modulate the activity of leukocytes [61-63]. The ischemic injury damages the barrier function of endothelium, resulting in disorganization of endothelial integrity producing partial disappearance of cell-cell borders and disruption of cell-cell contacts [46]. Endothelial disintegration thus increases vascular permeability and facilitates leukocyte infiltration into the renal parenchyma. Recent studies have investigated the leukocyte-endothelium interactions. Down regulation of Netrin-1, a protein involved in development of the nervous system and epithelial tissues, in renal vascular endothelial cells in peritubular capillaries may promote endothelial cell activation, resulting in extravasation of leukocytes into the kidney and tubular injury [64,65]. Furthermore, sphingosine-1-phosphate maintains endothelial cell integrity and inhibits lymphocyte extravasations via the sphingosine-1-phospate receptor. A recent study showed that a sphingosine-1-phosphate selective agonist ameliorates ischemic acute renal failure [66]. In addition to changes in the integrity of the renal vascular endothelium layer, IRI upregulates the expression of adhesion molecules, in particular intracellular adhesion molecule1 , that promote and facilitate the interactions between leukocytes and the endothelium $[29,67]$. Leukocyte adhesion causes inflammation and extension of cellular injury. Renal tubular epithelium is a major site of cell injury and cell death during AKI and numerous studies have suggested that renal epithelial cells have a central role in inflammation during AKI. This effect could modulate cell behavior in distant organs, such as the heart and lung, with potentially deleterious effects and creating a vicious circle.

\section{Immunomodulation: the role of innate and adaptive immunity}

Recent studies have highlighted the importance of both innate and adaptive immune responses to endogenous molecules induced by either tissue damage or infection $[68,69]$. The innate immune system is immediately activated in infection states and inflammatory conditions in a nonantigenic-specific way. This activation is executed primarily by myeloid cells with the participation of some innate lymphocyte subpopulations and is comprised of neutrophils, monocytes/macrophages, dendritic cells (DCs), natural killer cells and natural killer $\mathrm{T}$ cells (Figure 2). Leukocytes such as DCs and macrophages play important functions in both types of immunity by generating cytokines, chemokines and presenting antigens to lymphocytes $[29,68]$. Adaptative immunity is a second line of defense responding to specific antigens in cellular and humoral response pathways. T-cell polarization in response to DC activation is complex and involves myriads of signaling cascades. Critical signaling cascades from both intrinsic and extrinsic factors come down to a single bridge. Activation of both innate and adaptive immune responses is regulated by the TLR pathways. Briefly, DC maturation and antigen presentation, CD4 and CD8 lymphocyte proliferation and stimulation, and consequently T-lymphocyte to B-lymphocyte interactions lead to specific morphological and cell signaling upregulation. Specific subpopulations of $\mathrm{T}$ cells have been implicated in deleterious cell fate pathways, contributing to organ damage [70]. Proposed initiators of the innate immune response during AKI include the activation of TLRs and the release of ROS, reactive nitrogen species and mitochondrial products [71]. TLRs are the major pattern recognition receptors, binding to a wide range of different molecules and, in particular, endogenous ligands produced as a consequence of tissue injury. This pathogenesis, specifically TLR signaling, causes a rapid response mechanism to local tissue damage and is involved in early activation of the immune response in AKI events [15].

The adaptive immune system is stimulated by the specificity of antigen receptors on $\mathrm{B}$ and $\mathrm{T}$ lymphocytes that react to several antigenic molecular structures. Once stimulated, B cells produce specific antibodies, perform opsonization to encourage phagocytosis, and activate the complement system [15]. Antigen-dependent T-cell activation has been demonstrated in experimental models of renal IRI [61,72]. Inflammation of renal tissue stimulates 


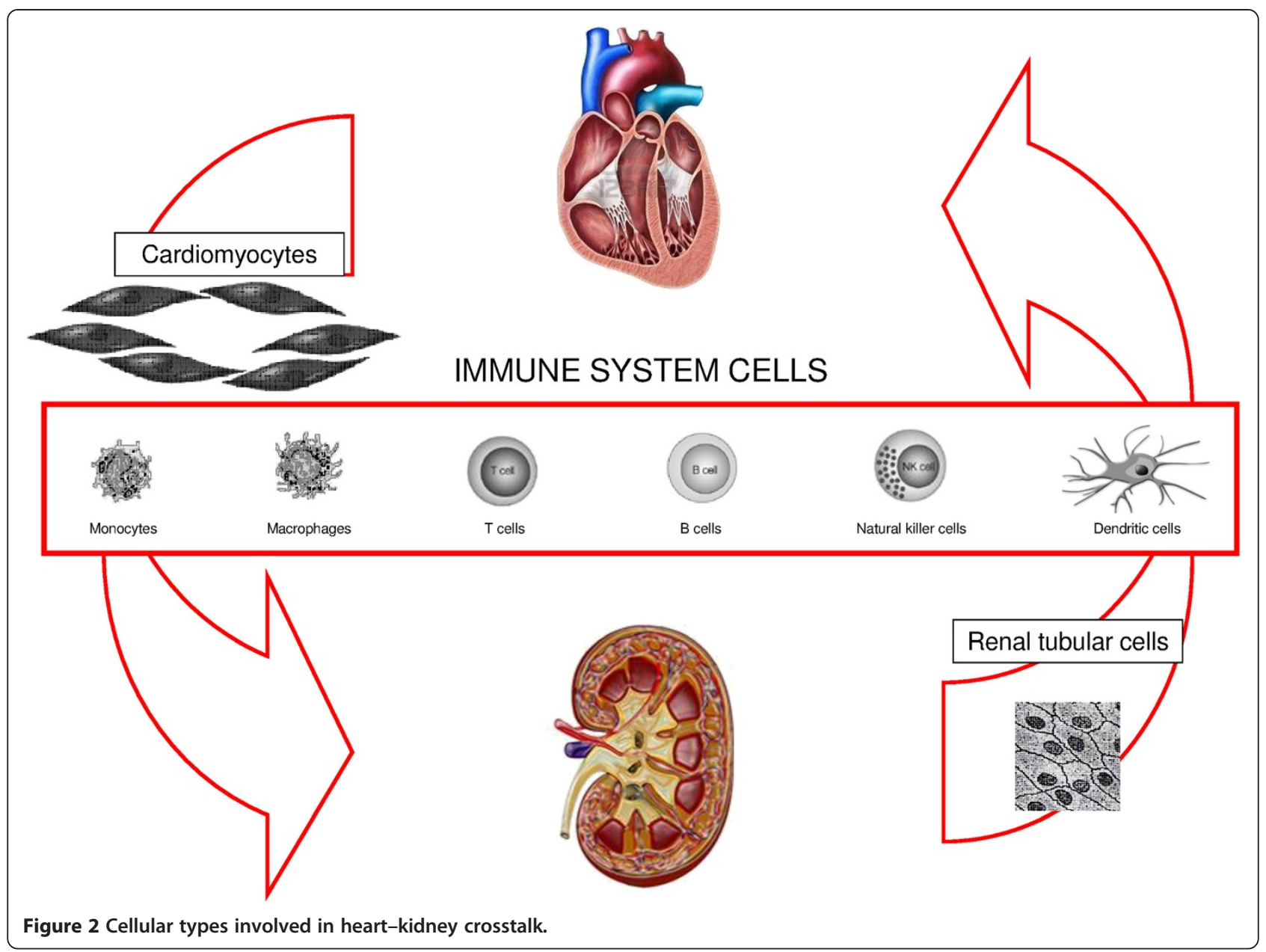

the expression of adhesion molecules in endothelial cells, which leads to the deposition of immune complexes and vascular stiffening in kidney disease $[15,73,74]$. Either following antigen activation or in the presence of chemokines and ROS/reactive nitrogen species, $\mathrm{T}$ cells undergo early activation and function as a bridge between adaptive and innate immune systems. This specific immune response in AKI facilitates and enhances distant heart-kidney crosstalk.

AKI is involved in the functional abnormalities in immune cell responsiveness and alterations such as leukocyte trafficking, adhesion and tissue extravasation both locally in the kidney and in distal organs such as the heart in CRS type 3. In ischemia animal models, morphological and functional changes in vascular endothelial cells and in tubular epithelium have been extensively confirmed $[29,46,75,76]$. Leukocyte activation and trafficking play a critical role in heart injury during AKI. Neutrophils, macrophages, natural killers and lymphocytes infiltrate into the injured kidneys. The injury prompts the activation of inflammatory pathways by tubular and endothelial cells recruiting leukocytes into the kidneys $[29,46]$. In particular, in IRI models, after adherence and chemotaxis, neutrophils release ROS, proteases, and myeloperoxidase, and other cardiorenal mediators directly damage the tissue with local and systemic effects including upregulation of proinflammatory cytokines and chemokines, both critical players in heart failure (HF) [77,78]. During AKI, chemokines recruit inflammatory cells with a consecutive neutrophil infiltration into the heart tissue and this is a causal factor of myocyte apoptosis [29,30], typical of CRS type 3.

The dominant resident leukocyte types present in the kidney are resident intrarenal DCs, suggesting a crucial role in renal immunity and inflammation. In fact, in the normal mouse $\mathrm{CD}_{11 \mathrm{c}^{+}}$major histocompatibility complex class $\mathrm{II}^{+}$DCs are the most abundant leukocyte subset in the kidney, suggesting an important role in renal immunity and inflammation [29]. Furthermore, intrarenal DCs are an important link between innate and adaptive immunity; unfortunately, the individual contribution of intrarenal DCs to the pathophysiology of AKI is not completely understood. These cells are located in the interstitial extracellular compartment of the whole 
kidney and are tactically positioned to interact with many different factors [79-81]. Within this compartment, DCs are close to epithelial cells, macrophages, and fibroblasts, and they respond to endogenous molecules released from resident and/or infiltrating cells [80-82]. DCs are a heterogeneous population with different functions. Upon stimulation, DCs can convert to a mature cell type characterized by high levels of class II major histocompatibility complex and co-stimulatory molecules and low phagocytic capacity. Mature DCs are specialized in T-cell activation. However, DCs are also important in the innate immune response by releasing proinflammatory factors, such as TNF, IL-6, IL-12, monocyte chemoattractant protein-1 and RANTES, and interacting with natural killer $\mathrm{T}$ cells via CD40-CD40L $[29,83]$. Recent studies have shown that DCs can improve or prevent injury to the kidney depending on the nature of stimulus. For example, depletion of DCs prior to IRI reduces consequent reperfusion injury and related renal dysfunction [84]. Conversely, depletion of DCs prior to cisplatin exposure resulted in worse renal dysfunction and stronger inflammation [85]. DCs have a central role in orchestrating the immune response in AKI; additional studies are needed to understand the detailed functions of these cells in the CRS and in the heart-kidney crosstalk.

\section{Role of inflammation, cytokines and chemokines}

The unbalancing of the cytokine and chemokine networks in inflammation accelerates the deposition of atherosclerotic plaques, mediates insulin resistance, stimulates tumor growth and causes increases in adhesion molecule expression and vascular permeability. Nonresolving and persistent exposure to proinflammatory factors, such as TNF $\alpha$, IL-1, IL-4, IL-6, IL-13, and IL-17, damages tissue, impairs organ function and is lethal in the critical care setting. The cytokines, chemokines, and eicosanoids mediate cellular responses and interact with genome-encoded receptors expressed on monocytes, macrophages, mast cells, astrocytes, and other cells of the innate immune system [86]. Upregulation of humoral factors by injured cells leads to activation of the toll/IL-1 superfamily. Members of this superfamily signal in a similar manner using a conserved domain that actives nuclear factor- $\mathrm{kB}$, which translocates the nucleus resulting in changes in gene expression. TLR pathways, activated via nuclear factor- $\mathrm{kB}$, result in both intracellular and extracellular upregulaton of inflammatory cytokine expression $[87,88]$.

Over the past 30 years there has been growing evidence for the role played by activation of the inflammatory response in the pathogenesis of acute events of HF at various levels in these patients $[89,90]$. Further support for the inflammatory etiology of HF came from the evidence that cytokines may also be produced by cardiomyocytes, following ischemic or mechanical stimuli, but also by innate immune response [91-93]. These findings suggest that an immune dysregulation may occur in HF; cytokines not only could provoke distant organ damage such as AKI and CRS type 1, but they may also play a role in concomitant damaging myocytes. In the Program to Improve Care in Acute Renal Disease, a prospective multicenter cohort study, TNF $\alpha$, IL-1 $\beta$, IL-6, IL- 8 and $\mathrm{C}$-reactive protein were increased in critically ill patients with acute renal failure [94]. These results provide evidence that an inflammatory systemic response is stimulated and maintained in critically ill patients with AKI that probably contributes to distant organ dysfunction, and in particular cardiac dysfunction.

Studies of CRS type 3 have expanded the understanding of heart-kidney crosstalk by demonstrating induction of cardiac damage by inflammatory mediators, oxidative stress and upregulation of neuroendocrine systems early following AKI [13,30,95].

In IRI animal models, AKI has been highlighted to elicit a systemic immune response characterized by a dose-response increase in circulating proinflammatory and anti-inflammatory factors. Likewise, AKI may be associated with physiologic derangements, alterations to coronary vasoreactivity, ventricular remodeling and fibrosis that indirectly strengthens negative effects on cardiomyocytes and causes cardiac dysfunction [96-98]. Several inflammatory mediators, such as TNF $\alpha$, IL-1 $\beta$ and IL-6, have been implicated in cardiodepressant effects, and cytokines can impact myocardial function due to both impaired myocyte contractility and extracellular matrix interaction $[95,98,99]$. In general, cytokinemediated contractile dysfunction is reversible over an extended time period of several days following exposure [95].

\section{Apoptosis}

TLR activation of cell-mediated, humoral, and inflammatory responses can lead to changes in cell fate, or in the worst case to continued heightened activation apoptotic induction. TLR induction of caspase-mediated apoptosis is a key pathogenic feature in kidney disease whereby renal tubular epithelial cells cease to proliferate and embark upon terminal differentiation. Apoptosis is a controlled and physiological mechanism of regulation of cell populations in an endogenously programmed pattern, and it plays a very important role especially in the immune system, during development of lymphocytes as in antigen recognition [100]. A loss of immune cells by apoptosis is associated with physiologic changes that occur in several diseases, and the host response requires a fine equilibrium between recruitment and death of immunocompetent cells [100]. 
Experimental evidence supports a pathogenic role for apoptosis in AKI and in the development of HF [101]. Two main intracellular pathways for apoptosis have been recognized: ligation of plasma membrane death receptors (extrinsic pathway), and perturbation of the intracellular homeostasis (intrinsic pathway). The two pathways are linked, and molecules in one pathway can influence the other [102]. In the extrinsic pathway, the Fas/Fas-ligand system transmits apoptotic signals from the surrounding environment into the cell; the binding of Fas ligand with Fas initiates receptor oligomerization, which recruits Fas-associated death domain and the activators caspase- 8 and caspase-10 [103-105]. These caspases are activated upon oligomerization and then cleave protein substrates to activate downstream effector caspases. The intrinsic pathway involves intracellular organelles, the most important being mitochondria [106-108]. The permeabilization of the outer mitochondrial membrane and the release of proapoptotic factors such as cytochrome c promote caspase-dependent and caspaseindependent apoptosis [106]. Caspases are widely expressed in an inactive proenzyme form in most cells and once activated can often activate other pro-caspases, allowing initiation of a protease cascade. This proteolytic cascade, in which one caspase can activate other caspases, amplifies the apoptotic signaling pathway and thus leads to rapid cell death $[109,110]$. Over the last few years, many studies have demonstrated that survival factors and anti-cytokine strategies can prevent apoptosis in vivo [111-114]; better characterization of the molecular pathways activated at each stage of apoptosis and an understanding of the time frames will be crucial to developing new sensible therapeutic strategies.

The multiple factors involved in the development of AKI during HF describe a pathogenesis of AKI accounting for multiple pathways. Evidence suggests that an immune-mediated mechanism has been implicated in CRS type 1 pathogenesis $[115,116]$. CRS type 1 plasmainduced apoptosis with caspase cascade and IL-6 were recently shown to be significantly higher in CRS type 1 patients when compared with healthy subjects and with HF patients without kidney impairment [115,116]. Limited data are available about cardiac-specific cellular responses associated with AKI, including the role of mitochondrial dysfunction, apoptosis, cardiac remodeling and fibrosis. Some experimental models have explained the role of apoptosis in AKI setting. Prolonged ischemia followed by reperfusion triggers apoptosis and inflammation, leading to tissue damage and organ dysfunction [117-119]. Cardiac myocyte apoptosis and neutrophil infiltration/activation are key contributors to the pathophysiology of myocardiac infarction during AKI, and transgenic rat models have shown that even apoptosis can lead to tissue damage and lethal heart dysfunction [30]. In particular, Kelly demonstrated that kidney IRI but not uremia is fundamental to trigger apoptosis in myocardial tissue [30]. Another experimental rat model of cisplatin-induced AKI showed significant increased levels of myocardial apoptosis by terminal deoxynucleotidyl transferase dUTP nick end-labeling assay [120]. Proinflammatory cytokine TNF $\alpha$ contributes directly to in vitro cardiomyocyte apoptosis depression of contractility, and to downregulation of sarcomeric proteins [121-123]. Furthermore, attenuation of apoptosis following administration of anti-TNF $\alpha$ antibodies was demonstrated and clearance of TNF $\alpha$ as a novel therapeutic strategy was hoped to improve HF [30].

\section{Cardiorenal syndrome type $\mathbf{5}$}

A brief part of this review is focused on CRS type 5, in which the heart and the kidney are both targets of a strong systemic inflammatory reaction [124]. CRS type 5 reflects concomitant cardiac and renal dysfunction in the setting of a wide spectrum of systemic disorders, such as diabetes mellitus, systemic lupus erythematosus and sepsis $[1,125,126]$. In CRS type 5 , cardiac dysfunction and renal dysfunction are often observed and are part of the clinical picture of severe sepsis, septic shock and multiple organ failure [1,127]. Following the RIFLE criteria, AKI ranges from minor alterations in renal function to indication for RRT in critically ill patients [128]. AKI is a common complication in septic patients and carries a poor prognosis. AKI occurs in $20 \%$ of critically ill patients, and in $51 \%$ of patients with septic shock and positive blood cultures [129]. Cardiac dysfunction in sepsis is characterized by decreased contractility, impaired ventricular response to fluid therapy, progressive ventricular dilatation and myocardial depression [124,127]. CRS type 5 is characterized by generalized inflammatory response and by activation of coagulation and the fibrinolytic system, and induces cellular and molecular changes in the heart and kidneys $[125,126,130]$. This inflammatory reaction is particularly relevant for sepsis in which the majority of mechanisms of immune-mediated heart and kidney tissue injury have been described in detail [131-134]. In particular, several studies have shown in critically ill patients that inflammatory mediators, release of nitric oxide and increased production of peroxynitrite are able to alter organ function and cause abnormal cell signaling, cell cycle arrest, and mitochondria dysfunction, and can induce direct proapoptotic and proinflammatory effects on cardiomyocytes and kidney resident cells such as podocytes, endothelial cells, mesangial cells and particularly tubular epithelial cells [3,124,135-140]. Recently, apoptosis was put forward as a major player in septic AKI [141]. Lerolle and colleagues studied kidney biopsies from 19 patients who died from septic shock and compared them 
with postmortem biopsies taken from eight trauma patients and from nine patients with nonseptic AKI. Acute tubular apoptosis was demonstrated by different techniques in septic AKI whereas almost no apoptosis was detected in the nonseptic AKI patients [141]. Indeed, inflammatory mediators, activation and induction of cytokines, leukocytes and toll receptors play a key role in the pathogenesis of renal and cardiac dysfunction during sepsis $[125,142]$. Inflammatory cytokines such as TNFa and IL-6 trigger apoptosis in tubular epithelial cells, probably playing a role in tissue damage, and TNF $\alpha$ and IL- 1 are the principal culprits in the pathogenesis of cardiac dysfunction during sepsis [137,143-146].

\section{Conclusions}

Immune response orchestrates healing and tissue generation, and eradication of pathogens, yet the danger of uncontrolled inflammation is a core homeostatic phenomenon in human disease and distant organ damage. Dysregulation of crosstalk between the heart and kidney is probably a therapeutic option, which currently includes cytokines, chemokines, and growth factors known to initiate intercellular and intracellular changes. Signaling pathways from damaged cells in either the heart or the kidney promote innate immune activation and strengthen adaptive immunity. Other targets may include serine/threonine kinases such as Akt capable of apoptotic cycle inhibition and repairing stimulation pathways in response to damage resulting from extracellular stimuli to control regulation of nutrient metabolism and survival [147]. Rapid characterization of cellular and subcellular research in human and animal models continues to elucidate the complex crosstalk as well as putative epigenetic changes resulting from brief or chronic states of immune-inflammatory changes in gene expression.

Heart-kidney crosstalk has significant clinical relevance, and the current review highlights the humoral mechanism involved in multiorgan failure. In particular, the management of acute CRS subtypes is challenging because of the multitude and complexity of pathophysiological interactions between the heart and the kidney and the possible progression from acute to chronic injury in these organs. In critical illness, the complete characterization of cellular and subcellular orchestration in heart-kidney crosstalk and the early recognition of disease by new biomarkers could allow choice of the best therapeutic options, prevention of the necessity for RRT, shorten the AKI duration, limit multiple organ injury and improve survival. The combination of clinical status and new functional and damage biomarkers provides a novel set of tools for the clinician to manage patients with CRS. Present and future studies on pathogenetic mechanisms involved in cardiorenal crosstalk will allow the development not only of better directed but also more appropriately timed therapeutic strategies to improve outcome in these patients.

\section{Abbreviations}

AKI: Acute kidney injury; CD40L: CD40 ligand; CRS: Cardiorenal syndrome; DC: Dendritic cell; HF: Heart failure; IL: Interleukin; IRI: Ischemia/reperfusion injury; RANTES: Regulated upon activation normal T-cell expressed and secreted; ROS: Reactive oxygen species; RRT: Renal replacement therapy; TLR: Toll-like receptor; TNF: Tumor necrosis factor.

\section{Competing interests}

The authors declare that they have no competing interests.

\section{Acknowledgements}

This work was supported by a research grant from Veneto Region (RSF N. 303/2009).

\section{Author details}

'Department of Nephrology, Dialysis and Transplantation, San Bortolo Hospital, International Renal Research Institute Vicenza, Via Rodolfi 37, Vicenza 36100, Italy. ${ }^{2}$ IRRIV - International Renal Resarch Institute Vicenza, Via Rodolfi 37, Vicenza 36100, Italy. ${ }^{3}$ Clinical Genetics Unit, Department of Women's and Children's Health, University of Padua, Padua, Italy. ${ }^{4}$ Internal Medicine, San Bortolo Hospital, Vicenza, Via Giustiniani, Padua 35128, Italy.

\section{Published: 06 Jan 2014}

\section{References}

1. Ronco C, Haapio M, House AA, Anavekar N, Bellomo R: Cardiorenal syndrome. J Am Coll Cardiol 2008, 52:1527-1539.

2. Goh CY, Vizzi G, De Cal M, Ronco C: Cardiorenal syndrome: a complex series of combined heart/kidney disorders. Contrib Nephrol 2011, 174:33-45.

3. McCullough PA, Kellum JA, Haase M, Müller C, Damman K, Murray PT, Cruz D, House AA, Schmidt-Ott KM, Vescovo G, Bagshaw SM, Hoste EA, Briguori C, Braam B, Chawla LS, Costanzo MR, Tumlin JA, Herzog CA, Mehta RL, Rabb $H$, Shaw AD, Singbartl K, Ronco C: Pathophysiology of the cardiorenal syndromes: executive summary from the eleventh consensus conference of the acute dialysis quality initiative (ADQI). Contrib Nephrol 2013, 182:82-98.

4. Bagshaw SM, Cruz DN, Aspromonte N, Daliento L, Ronco F, Sheinfeld G, Anker SD, Anand I, Bellomo R, Berl T, Bobek I, Davenport A, Haapio M, Hillege H, House A, Katz N, Maisel A, Mankad S, McCullough P, Mebazaa A, Palazzuoli A, Ponikowski P, Shaw A, Soni S, Vescovo G, Zamperetti N, Zanco $P$, Ronco $C$ : Acute dialysis quality initiative consensus group: epidemiology of cardio-renal syndromes: workgroup statements from the 7th ADQI consensus conference. Nephrol Dial Transplant 2010, 25:1406-1416.

5. Grams ME, Rabb H: The distant organ effects of acute kidney injury. Kidney Int 2012, 81:942-948.

6. Okusa MD: The changing pattern of acute kidney injury: from one to multiple organ failure. Contrib Nephrol 2010, 165:153-158.

7. Uchino S, Kellum JA, Bellomo R, Doig GS, Morimatsu H, Morgera S, Schetz M, Tan I, Bouman C, Macedo E, Gibney N, Tolwani A, Ronco C: Acute renal failure in critically ill patients: a multinational, multicenter study. JAMA 2005, 294:813-818

8. Lameire N, Van Biesen W, Vanholder R: The changing epidemiology of acute renal failure. Nat Clin Pract Nephrol 2006, 2:364-377.

9. Waikar SS, Liu KD, Chertow GM: The incidence and prognostic significance of acute kidney injury. Curr Opin Nephrol Hypertens 2007, 16:227-236.

10. Esson ML, Schrier RW: Diagnosis and treatment of acute tubular necrosis. Ann Intern Med 2002, 137:744-752.

11. Palevsky PM: Renal replacement therapy in acute kidney injury. Adv Chronic Kidney Dis 2013, 20:76-84

12. Kelly K, Molitoris BA: Acute renal failure in the new millennium: time to consider combination therapy. Semin Nephrol 2000, 20:4-19.

13. Yap SC, Lee HT: Acute kidney injury and extrarenal organ dysfunction: new concepts and experimental evidence. Anesthesiology 2012, 116:1139-1148. 
14. Levy EM, Viscoli CM, Horwitz RI: The effect of acute renal failure on mortality. A cohort analysis. JAMA 1996, 275:1489-1494.

15. White $L E$, Hassoun $H T$ : Inflammatory mechanisms of organ crosstalk during ischemic acute kidney injury. Int J Nephrol 2012, 2012:505197.

16. Ko GJ, Rabb H, Hassoun HT: Kidney-lung crosstalk in the critically ill patient. Blood Purif 2009, 28:75-83.

17. Basu RK, Wheeler DS: Kidney-lung cross-talk and acute kidney injury. Pediatr Nephrol 2013. Epub ahead of print.

18. Singbartl K: Renal-pulmonary crosstalk. Contrib Nephrol 2011, 174:65-70.

19. Sural S, Sharma RK, Gupta A, Sharma AP, Gulati S: Acute renal failure associated with liver disease in India: etiology and outcome. Ren Fail 2000, 22:623-634.

20. Serteser M, Koken T, Kahraman A, Yilmaz K, Akbulut G, Dilek ON: Changes in hepatic TNF-alpha levels, antioxidant status, and oxidation products after renal ischemia/reperfusion injury in mice. J Surg Res 2002, 107:234-240.

21. Canbay A, Friedman S, Gores GJ: Apoptosis: the nexus of liver injury and fibrosis. Hepatology 2004, 39:273-278.

22. Jaeschke H: Inflammation in response to hepatocellular apoptosis. Hepatology 2002, 35:964-966.

23. White LE, Chaudhary R, Moore LJ, Moore FA, Hassoun HT: Surgical sepsis and organ crosstalk: the role of the kidney. J Surg Res 2011, 167:306-315.

24. Nadim MK, Kellum JA, Davenport A, Wong F, Davis C, Pannu N, Tolwani A, Bellomo R, Genyk YS: Hepatorenal syndrome: the 8th international consensus conference of the acute dialysis quality initiative (ADQI) group. Crit Care 2012, 16:R23.

25. Angeli P, Morando F, Cavallin M, Piano S: Hepatorenal syndrome. Contrib Nephrol 2011, 174:46-55.

26. Brouns R, De Deyn PP: Neurological complications in renal failure: a review. Clin Neurol Neurosurg 2004, 107:1-16.

27. Li X, Hassoun HT, Santora R, Rabb H: Organ crosstalk: the role of the kidney. Curr Opin Crit Care 2009, 15:481-487.

28. Liu M, Liang Y, Chigurupati S, Lathia JD, Pletnikov M, Sun Z, Crow M, Ross CA, Mattson MP, Rabb H: Acute kidney injury leads to inflammation and functional changes in the brain. J Am Soc Nephrol 2008, 19:1360-1370.

29. Kinsey GR, Li L, Okusa MD: Inflammation in acute kidney injury. Nephron Exp Nephrol 2008, 109:e102-e107.

30. Kelly KJ: Distant effects of experimental renal ischemia/reperfusion injury. J Am Soc Nephrol 2003, 14:1549-1558.

31. Gill R, Tsung A, Billiar T: Linking oxidative stress to inflammation: toll-like receptors. Free Radic Biol Med 2010, 48:1121-1132.

32. Feltes $C M$, Van Eyk J, Rabb H: Distant-organ changes after acute kidney injury. Nephron Physiol 2008, 109:p80-p84.

33. Molls RR, Rabb H: Limiting deleterious cross-talk between failing organs. Crit Care Med 2004, 32:2358-2359.

34. Paladino JD, Hotchkiss JR, Rabb H: Acute kidney injury and lung dysfunction: a paradigm for remote organ effects of kidney disease? Microvasc Res 2009, 77:8-12.

35. Waeckerle-Men Y, Starke A, Wuthrich RP: PD-L1 partially protects renal tubular epithelial cells from the attack of $\mathrm{CD} 8^{+}$cytotoxic T cells. Nephrol Dial Transplant 2007, 22:1527-1536.

36. Waeckerle-Men Y, Starke A, Wahl PR, Wuthrich RP: Limited costimulatory molecule expression on renal tubular epithelial cells impairs T cell activation. Kidney Blood Press Res 2007, 30:421-429.

37. Jevnikar AM, Brennan DC, Singer GG, Heng JE, Maslinski W, Wuthrich RP, Glimcher LH, Kelley VE: Stimulated kidney tubular epithelial cells express membrane associated and secreted TNF alpha. Kidney Int 1991, 40:203-211.

38. Schmouder RL, Strieter RM, Wiggins RC, Chensue SW, Kunkel SL: In vitro and in vivo interleukin-8 production in human renal cortical epithelia. Kidney Int 1992, 41:191-198.

39. Nechemia-Arbely Y, Barkan D, Pizov G, Shriki A, Rose-John S, Galun E, Axelrod JH: IL-6/IL-6R axis plays a critical role in acute kidney injury. J Am Soc Nephrol 2008, 19:1106-1115.

40. Pontrelli P, Ursi M, Ranieri E, Capobianco C, Schena FP, Gesualdo L, Grandaliano G: CD40L proinflammatory and profibrotic effects on proximal tubular epithelial cells: role of NF-kappaB and lyn. J Am Soc Nephrol 2006, 17:627-636.

41. van Kooten C, Gerritsma JS, Paape ME, van Es LA, Banchereau J, Daha MR: Possible role for CD40-CD40L in the regulation of interstitial infiltration in the kidney. Kidney Int 1997, 51:711-721.
42. Li H, Nord EP: CD40 ligation stimulates MCP-1 and IL-8 production, TRAF6 recruitment, and MAPK activation in proximal tubule cells. Am J Physiol Renal Physiol 2002, 282:F1020-F1033.

43. Gerritsma JS, van Kooten C, Gerritsen AF, van Es LA, Daha MR: Transforming growth factor-beta 1 regulates chemokine and complement production by human proximal tubular epithelial cells. Kidney Int 1998, 53:609-616.

44. van Kooten C, Woltman AM, Daha MR: Immunological function of tubular epithelial cells: the functional implications of CD40 expression. Exp Nephrol 2000, 8:203-207.

45. Laxmanan S, Datta D, Geehan C, Briscoe DM, Pal S: CD40: a mediator of pro- and anti-inflammatory signals in renal tubular epithelial cells. J Am Soc Nephrol 2005, 16:2714-2723.

46. Akcay A, Nguyen Q, Edelstein CL: Mediators of inflammation in acute kidney injury. Mediators Inflamm 2009, 2009:137072.

47. Schober A, Zernecke A: Chemokines in vascular remodeling. Thromb Haemost 2007, 97:730-737.

48. Mann DL: Inflammatory mediators and the failing heart: past, present, and the foreseeable future. Circ Res 2002, 91:988-998.

49. Paulus WJ: Cytokines and heart failure. Heart Fail Monit 2000, 1:50-56

50. Ramesh G, Reeves WB: Inflammatory cytokines in acute renal failure. Kidney Int Suppl 2004, 91:S56-S61.

51. Camussi G, Deregibus MC, Cantaluppi V: Role of stem-cell-derived microvesicles in the paracrine action of stem cells. Biochem Soc Trans 2013, 41:283-287.

52. Struthers AD: Pathophysiology of heart failure following myocardial infarction. Heart 2005, 91:ii14-ii16. discussion ii31, ii43-ii48.

53. Wang Y, John R, Chen J, Richardson JA, Shelton JM, Bennett M, Zhou XJ, Nagami GT, Zhang Y, Wu QQ, Lu CY: IRF-1 promotes inflammation early after ischemic acute kidney injury. J Am Soc Nephrol 2009, 20:1544-1555.

54. Healy S, Khan DH, Davie JR: Gene expression regulation through 14-3-3 interactions with histones and HDACs. Discov Med 2011, 11:349-358.

55. Banerjee T, Chakravarti D: A peek into the complex realm of histone phosphorylation. Mol Cell Biol 2011, 31:4858-4873.

56. Zager RA, Johnson AC: Renal ischemia-reperfusion injury upregulates histone-modifying enzyme systems and alters histone expression at proinflammatory/profibrotic genes. Am J Physiol Renal Physiol 2009, 296: F1032-F1041.

57. Zager RA, Johnson AC: Progressive histone alterations and proinflammatory gene activation: consequences of heme protein/ironmediated proximal tubule injury. Am J Physiol Renal Physiol 2010, 298: F827-F837.

58. Zager RA: 'Biologic memory' in response to acute kidney injury: cytoresistance, toll-like receptor hyper-responsiveness and the onset of progressive renal disease. Nephrol Dial Transplant 2013, 28:1985-1993.

59. Allam R, Scherbaum CR, Darisipudi MN, Mulay SR, Hagele H, Lichtnekert J, Hagemann JH, Rupanagudi KV, Ryu M, Schwarzenberger C, Hohenstein B, Hugo C, Uhl B, Reichel CA, Krombach F, Monestier M, Liapis H, Moreth K, Schaefer $L$, Anders $\mathrm{HJ}$ : Histones from dying renal cells aggravate kidney injury via TLR2 and TLR4. J Am Soc Nephrol 2012, 23:1375-1388.

60. Molitoris BA, Sutton TA: Endothelial injury and dysfunction: role in the extension phase of acute renal failure. Kidney Int 2004, 66:496-499.

61. Ascon DB, Lopez-Briones S, Liu M, Ascon M, Savransky V, Colvin RB, Soloski MJ, Rabb H: Phenotypic and functional characterization of kidneyinfiltrating lymphocytes in renal ischemia reperfusion injury. I Immunol 2006, 177:3380-3387.

62. Linas SL, Whittenburg D, Parsons PE, Repine JE: Ischemia increases neutrophil retention and worsens acute renal failure: role of oxygen metabolites and ICAM 1. Kidney Int 1995, 48:1584-1591.

63. Kluth DC, Erwig LP, Rees AJ: Multiple facets of macrophages in renal injury. Kidney Int 2004, 66:542-557.

64. Wang W, Reeves WB, Ramesh G: Netrin-1 and kidney injury. I. Netrin-1 protects against ischemia-reperfusion injury of the kidney. Am J Physiol Renal Physiol 2008, 294:F739-F747.

65. Bradford D, Cole SJ, Cooper HM: Netrin-1: diversity in development. Int $J$ Biochem Cell Biol 2009, 41:487-493.

66. Lien YH, Yong KC, Cho C, Igarashi S, Lai LW: S1P(1)-selective agonist, SEW2871, ameliorates ischemic acute renal failure. Kidney Int 2006, 69:1601-1608.

67. Kelly KJ, Williams WW Jr, Colvin RB, Meehan SM, Springer TA, GutierrezRamos JC, Bonventre JV: Intercellular adhesion molecule-1-deficient mice 
are protected against ischemic renal injury. J Clin Invest 1996, 97:1056-1063.

68. Shalhoub J, Falck-Hansen MA, Davies AH, Monaco C: Innate immunity and monocyte-macrophage activation in atherosclerosis. J Inflamm (Lond) 2011, 8:9.

69. Mogensen $\mathrm{TH}$ : Pathogen recognition and inflammatory signaling in innate immune defenses. Clin Microbiol Rev 2009, 22:240-273.

70. Rabb H: The T cell as a bridge between innate and adaptive immune systems: implications for the kidney. Kidney Int 2002, 61:1935-1946.

71. Chakraborti T, Mandal A, Mandal M, Das S, Chakraborti S: Complement activation in heart diseases. Role of oxidants. Cell Signal 2000, 12:607-617.

72. Hochegger K, Schatz T, Eller P, Tagwerker A, Heininger D, Mayer G, Rosenkranz AR: Role of alpha/beta and gamma/delta T cells in renal ischemia-reperfusion injury. Am J Physiol Renal Physiol 2007, 293:F741-F747.

73. Silverstein DM: Inflammation in chronic kidney disease: role in the progression of renal and cardiovascular disease. Pediatr Nephrol 2009, 24:1445-1452

74. Chen J, John R, Richardson JA, Shelton JM, Zhou XJ, Wang Y, Wu QQ, Hartono JR, Winterberg PD, LU CY: Toll-like receptor 4 regulates early endothelial activation during ischemic acute kidney injury. Kidney Int 2011, 79:288-299.

75. Devarajan P: Update on mechanisms of ischemic acute kidney injury. $J$ Am Soc Nephrol 2006, 17:1503-1520

76. Sutton TA: Alteration of microvascular permeability in acute kidney injury. Microvasc Res 2009, 77:4-7.

77. Givertz MM, Colucci WS: New targets for heart-failure therapy: endothelin, inflammatory cytokines, and oxidative stress. Lancet 1998, 352:SI34-SI38.

78. Chuasuwan A, Kellum JA: Cardio-renal syndrome type 3: epidemiology, pathophysiology, and treatment. Semin Nephrol 2012, 32:31-39.

79. Okusa MD, Li L: Dendritic cells in acute kidney injury: cues from the microenvironment. Trans Am Clin Climatol Assoc 2012, 123:54-62. discussion 62-63.

80. Kinsey GR, Okusa MD: Role of leukocytes in the pathogenesis of acute kidney injury. Crit Care 2012, 16:214.

81. Kaissling B, Le Hir M: Characterization and distribution of interstitial cell types in the renal cortex of rats. Kidney Int 1994, 45:709-720.

82. Rosner MH, Ronco C, Okusa MD: The role of inflammation in the cardiorenal syndrome: a focus on cytokines and inflammatory mediators. Semin Nephrol 2012, 32:70-78.

83. Dong $X$, Swaminathan S, Bachman LA, Croatt AJ, Nath KA, Griffin MD: Resident dendritic cells are the predominant TNF-secreting cell in early renal ischemia-reperfusion injury. Kidney Int 2007, 71:619-628.

84. Li L, Okusa MD: Macrophages, dendritic cells, and kidney ischemiareperfusion injury. Semin Nephrol 2010, 30:268-277.

85. Tadagavadi RK, Reeves WB: Renal dendritic cells ameliorate nephrotoxic acute kidney injury. J Am Soc Nephrol 2010, 21:53-63.

86. Benoist C, Mathis D: Mast cells in autoimmune disease. Nature 2002, 420:875-878.

87. Murakami M, Hirano T: The pathological and physiological roles of IL-6 amplifier activation. Int J Biol Sci 2012, 8:1267-1280.

88. Tornatore L, Thotakura AK, Bennett J, Moretti M, Franzoso G: The nuclear factor kappa B signaling pathway: integrating metabolism with inflammation. Trends Cell Biol 2012, 22:557-566.

89. Wrigley BJ, Lip GY, Shantsila E: The role of monocytes and inflammation in the pathophysiology of heart failure. Eur J Heart Fail 2011, 13:1161-1171.

90. Ronco C, Cicoira M, McCullough PA: Cardiorenal syndrome type 1: pathophysiological crosstalk leading to combined heart and kidney dysfunction in the setting of acutely decompensated heart failure. $J$ Am Coll Cardiol 2012, 60:1031-1042.

91. Torre-Amione G: Immune activation in chronic heart failure. Am J Cardiol 2005, 95:3C-8C. discussion 38C-40C

92. Aukrust $\mathrm{P}$, Ueland $\mathrm{T}$, Lien $\mathrm{E}$, Bendtzen $\mathrm{K}$, Muller $\mathrm{F}$, Andreassen AK, Nordoy Aass H, Espevik T, Simonsen S, Frøland SS, Gullestad L: Cytokine network in congestive heart failure secondary to ischemic or idiopathic dilated cardiomyopathy. Am J Cardiol 1999, 83:376-382.

93. Deswal A, Petersen NJ, Feldman AM, Young JB, White BG, Mann DL: Cytokines and cytokine receptors in advanced heart failure: an analysis of the cytokine database from the Vesnarinone trial (VEST). Circulation 2001, 103:2055-2059.
94. Simmons EM, Himmelfarb J, Sezer MT, Chertow GM, Mehta RL, Paganini EP Soroko S, Freedman S, Becker K, Spratt D, Shyr Y, Ikizler TA: PICARD study group: plasma cytokine levels predict mortality in patients with acute renal failure. Kidney Int 2004, 65:1357-1365.

95. Prabhu SD: Cytokine-induced modulation of cardiac function. Circ Res 2004, 95:1140-1153.

96. Zager RA, Johnson AC, Lund S: Uremia impacts renal inflammatory cytokine gene expression in the setting of experimental acute kidney injury. Am J Physiol Renal Physiol 2009, 297:F961-F970.

97. Kingma JG Jr, Vincent C, Rouleau JR, Kingma I: Influence of acute renal failure on coronary vasoregulation in dogs. J Am Soc Nephrol 2006 17:1316-1324.

98. Sharma UC, Pokharel S, van Brakel TJ, van Berlo JH, Cleutjens JP, Schroen B, Andre S, Crijns HJ, Gabius HJ, Maessen J, Pinto YM: Galectin-3 marks activated macrophages in failure-prone hypertrophied hearts and contributes to cardiac dysfunction. Circulation 2004, 110:3121-3128.

99. Bongartz LG, Cramer MJ, Doevendans PA, Joles JA, Braam B: The severe cardiorenal syndrome: 'Guyton revisited'. Eur Heart J 2005, 26:11-17.

100. Cohen JJ, Duke RC, Fadok VA, Sellins KS: Apoptosis and programmed cell death in immunity. Annu Rev Immunol 1992, 10:267-293.

101. Havasi A, Borkan SC: Apoptosis and acute kidney injury. Kidney Int 2011, 80:29-40.

102. Igney FH, Krammer PH: Death and anti-death: tumour resistance to apoptosis. Nat Rev Cancer 2002, 2:277-288.

103. Chinnaiyan AM, O'Rourke $K$, Tewari M, Dixit VM: FADD, a novel death domain-containing protein, interacts with the death domain of Fas and initiates apoptosis. Cell 1995, 81:505-512.

104. Ashkenazi A, Dixit VM: Apoptosis control by death and decoy receptors. Curr Opin Cell Biol 1999, 11:255-260.

105. Thorburn A: Death receptor-induced cell killing. Cell Signal 2004 16:139-144.

106. Sanz AB, Santamaria B, Ruiz-Ortega M, Egido J, Ortiz A: Mechanisms of renal apoptosis in health and disease. J Am Soc Nephrol 2008, 19:1634-1642.

107. Riedl SJ, Salvesen GS: The apoptosome: signalling platform of cell death. Nat Rev Mol Cell Biol 2007, 8:405-413.

108. Green DR, Kroemer G: The pathophysiology of mitochondrial cell death. Science 2004, 305:626-629.

109. Elmore S: Apoptosis: a review of programmed cell death. Toxicol Pathol 2007, 35:495-516.

110. Kaushal GP: Role of caspases in renal tubular epithelial cell injury. Semin Nephrol 2003, 23:425-431.

111. Sharples EJ, Patel N, Brown P, Stewart K, Mota-Philipe H, Sheaff M, Kieswich J, Allen D, Harwood S, Raftery M, Thiemermann C, Yaqoob MM: Erythropoietin protects the kidney against the injury and dysfunction caused by ischemia-reperfusion. J Am Soc Nephrol 2004, 15:2115-2124

112. Vijayan A, Martin DR, Sadow JL, Kissane J, Miller SB: Hepatocyte growth factor inhibits apoptosis after ischemic renal injury in rats. Am J Kidney Dis 2001, 38:274-278.

113. Hirschberg R, Kopple J, Lipsett P, Benjamin E, Minei J, Albertson T, Munger M, Metzler M, Zaloga G, Murray M, Lowry S, Conger J, McKeown W, O'shea M, Baughman R, Wood K, Haupt M, Kaiser R, Simms H, Warnock D, Summer W, Hintz R, Myers B, Haenftling K, Capra W, Pike M, Guler HP: Multicenter clinical trial of recombinant human insulin-like growth factor I in patients with acute renal failure. Kidney Int 1999, 55:2423-2432.

114. Hladunewich MA, Corrigan G, Derby GC, Ramaswamy D, Kambham N, Scandling JD, Myers BD: A randomized, placebo-controlled trial of IGF-1 for delayed graft function: a human model to study postischemic ARF. Kidney Int 2003, 64:593-602.

115. Virzi GM, de Cal M, Cruz DN, Bolin C, Vescovo G, Ronco C: [Type 1 cardiorenal syndrome and its possible pathophysiological mechanisms]. $G$ Ital Nefrol 2012, 29:690-698.

116. Virzi GM, Torregrossa R, Cruz DN, Chionh CY, de Cal M, Soni SS, Dominici M, Vescovo G, Rosner $\mathrm{MH}$, Ronco C: Cardiorenal syndrome type 1 may be immunologically mediated: a pilot evaluation of monocyte apoptosis. Cardiorenal Med 2012, 2:33-42.

117. Anker SD, Coats AJ: How to recover from renaissance? The significance of the results of recover, renaissance, renewal and attach. Int J Cardiol 2002, 86:123-130.

118. Momii H, Shimokawa H, Oyama J, Cheng XS, Nakamura R, Egashira K, Nakazawa $H$, Takeshita A: Inhibition of adhesion molecules markedly 
ameliorates cytokine-induced sustained myocardial dysfunction in dogs in vivo. J Mol Cell Cardiol 1998, 30:2637-2650.

119. Daemen MA, Van't Veer C, Denecker G, Heemskerk VH, Wolfs TG, Clauss M, Vandenabeele P, Buurman WA: Inhibition of apoptosis induced by ischemia-reperfusion prevents inflammation. J Clin Invest 1999, 104:541-549.

120. Kelly KJ, Meehan SM, Colvin RB, Williams WW, Bonventre JV: Protection from toxicant-mediated renal injury in the rat with anti-CD54 antibody. Kidney Int 1999, 56:922-931.

121. Krown KA, Page MT, Nguyen C, Zechner D, Gutierrez V, Comstock KL, Glembotski CC, Quintana PJ, Sabbadini RA: Tumor necrosis factor alphainduced apoptosis in cardiac myocytes. Involvement of the sphingolipid signaling cascade in cardiac cell death. J Clin Invest 1996, 98:2854-2865.

122. Muller-Werdan U, Schumann H, Fuchs R, Reithmann C, Loppnow H, Koch S, Zimny-Arndt U, He C, Darmer D, Jungblut P, Stadler J, Holtz J, Werdan K: Tumor necrosis factor alpha (TNF alpha) is cardiodepressant in pathophysiologically relevant concentrations without inducing inducible nitric oxide-(NO)-synthase (iNOS) or triggering serious cytotoxicity. J Mol Cell Cardiol 1997, 29:2915-2923.

123. Patten M, Kramer E, Bunemann J, Wenck C, Thoenes M, Wieland T, Long C: Endotoxin and cytokines alter contractile protein expression in cardiac myocytes in vivo. Pflugers Arch 2001, 442:920-927.

124. Chelazzi C, Villa G, De Gaudio AR: Cardiorenal syndromes and sepsis. Int $J$ Nephrol 2011, 2011:652967.

125. Soni SS, Ronco C, Pophale R, Bhansali AS, Nagarik AP, Barnela SR, Saboo SS, Raman A: Cardio-renal syndrome type 5: epidemiology, pathophysiology, and treatment. Semin Nephrol 2012, 32:49-56.

126. Mehta RL, Rabb H, Shaw AD, Singbartl K, Ronco C, McCullough PA, Kellum JA: Cardiorenal syndrome type 5: clinical presentation, pathophysiology and management strategies from the eleventh consensus conference of the acute dialysis quality initiative (ADQI). Contrib Nephrol 2013, 182:174-194.

127. Srisawat N, Hoste EE, Kellum JA: Modern classification of acute kidney injury. Blood Purif 2010, 29:300-307.

128. Bagshaw SM, George C, Dinu I, Bellomo R: A multi-centre evaluation of the RIFLE criteria for early acute kidney injury in critically ill patients. Nephrol Dial Transplant 2008, 23:1203-1210.

129. Rangel-Frausto MS, Pittet D, Costigan M, Hwang T, Davis CS, Wenzel RP: The natural history of the systemic inflammatory response syndrome (SIRS). A prospective study. JAMA 1995, 273:117-123.

130. Aziz M, Jacob A, Yang WL, Matsuda A, Wang P: Current trends in inflammatory and immunomodulatory mediators in sepsis. J Leukoc Biol 2013, 93:329-342.

131. Lee SY, Lee YS, Choi HM, Ko YS, Lee HY, Jo SK, Cho WY, Kim HK: Distinct pathophysiologic mechanisms of septic acute kidney injury: role of immune suppression and renal tubular cell apoptosis in murine model of septic acute kidney injury. Crit Care Med 2012, 40:2997-3006.

132. Jacobs R, Honore PM, Joannes-Boyau O, Boer W, De Regt J, De Waele E, Collin V, Spapen HD: Septic acute kidney injury: the culprit is inflammatory apoptosis rather than ischemic necrosis. Blood Purif 2011, 32:262-265.

133. Takasu O, Gaut JP, Watanabe E, To K, Fagley RE, Sato B, Jarman S, Efimov IR, Janks DL, Srivastava A, Bhayani SB, Drewry A, Swanson PE, Hotchkiss RS: Mechanisms of cardiac and renal dysfunction in patients dying of sepsis. Am J Respir Crit Care Med 2013, 187:509-517.

134. Balija TM, Lowry SF: Lipopolysaccharide and sepsis-associated myocardial dysfunction. Curr Opin Infect Dis 2011, 24:248-253.

135. Buerke U, Carter JM, Schlitt A, Russ M, Schmidt H, Sibelius U, Grandel U, Grimminger F, Seeger W, Mueller-Werdan U, Werdan K, Buerke M: Apoptosis contributes to septic cardiomyopathy and is improved by simvastatin therapy. Shock 2008, 29:497-503.

136. Merx MW, Weber C: Sepsis and the heart. Circulation 2007, 116:793-802.

137. Oudemans-van Straaten HM: Circulating pro-apoptotic mediators in burn septic acute renal failure. Crit Care 2008, 12:126.

138. Cantaluppi V, Assenzio B, Pasero D, Romanazzi GM, Pacitti A, Lanfranco G, Puntorieri V, Martin EL, Mascia L, Monti G, Casella G, Segoloni GP, Camussi $G$, Ranieri VM: Polymyxin-B hemoperfusion inactivates circulating proapoptotic factors. Intensive Care Med 2008, 34:1638-1645.

139. Mariano F, Cantaluppi V, Stella M, Romanazzi GM, Assenzio B, Cairo M, Biancone L, Triolo G, Ranieri VM, Camussi G: Circulating plasma factors induce tubular and glomerular alterations in septic burns patients. Crit Care 2008, 12:R42.
140. Kockara A, Kayatas M: Renal cell apoptosis and new treatment options in sepsis-induced acute kidney injury. Ren Fail 2013, 35:291-294.

141. Lerolle N, Nochy D, Guerot E, Bruneval P, Fagon JY, Diehl JL, Hill G: Histopathology of septic shock induced acute kidney injury: apoptosis and leukocytic infiltration. Intensive Care Med 2010, 36:471-478.

142. Celes MR, Prado CM, Rossi MA: Sepsis: going to the heart of the matter. Pathobiology 2013, 80:70-86.

143. Cantaluppi V, Weber V, Lauritano C, Figliolini F, Beltramo S, Biancone L, De Cal M, Cruz D, Ronco C, Segoloni GP, Tetta C, Camussi G: Protective effect of resin adsorption on septic plasma-induced tubular injury. Crit Care 2010, 14:R4.

144. Novaes AB Jr, de Uzeda M, Fonseca ME, Feitosa AC: The effect of subinhibitory concentrations of metronidazole and tetracycline on the ultrastructure of periodontopathic bacteria. J Antimicrob Chemother 1991 28:151-154.

145. Horton JW, Maass D, White J, Sanders B: Nitric oxide modulation of TNFalpha-induced cardiac contractile dysfunction is concentration dependent. Am J Physiol Heart Circ Physiol 2000, 278:H1955-H1965.

146. Francis SE, Holden H, Holt CM, Duff GW: Interleukin-1 in myocardium and coronary arteries of patients with dilated cardiomyopathy. J Mol Cell Cardiol 1998, 30:215-223.

147. Mullonkal CJ, Toledo-Pereyra LH: Akt in ischemia and reperfusion. J Invest Surg 2007, 20:195-203

\section{$10.1186 / \mathrm{cc} 13177$}

Cite this article as: Virzi et al:: Heart-kidney crosstalk and role of humoral signaling in critical illness. Critical Care 2014, 18:201 